\title{
Implementasi Kebijakan Energi Baru dan Energi Terbarukan Dalam Rangka Ketahanan Energi Nasional
}

\author{
Muhamad Azhar \\ Fakultas Hukum, Universitas Diponegoro \\ azhar@live.undip.ac.id \\ Dendy Adam Satriawan \\ Mahasiswa Fakultas Hukum, Universitas Diponegoro \\ dendysatria603@gmail.com
}

\begin{abstract}
This study aims to determine the implementation of new energy and renewable energy policies in the context of national energy security. The research method used is legal research that uses a regulatory approach. The results of the study show that the implementation of new energy and renewable energy policies in the context of national energy security has proceeded as it should. This can be seen from the role of the government in making policies (beleid) and management actions (bestuursdaad), arrangements (regelendaad), management (beheersdaad) and supervision (toezichthoudensdaad) for the purpose of maximizing the people's prosperity.
\end{abstract}

Keywords: Energy Policy, Renewable Energy, National Energy Security

\begin{abstract}
Abstrak
Penelitian ini bertujuan untuk mengetahui Implementasi kebijakan energi baru dan energi terbarukan dalam rangka ketahanan energy nasional. Metode penelitian yang diguankan adalah penelitian hukum yang menggunakan pendekatan peraturan perundang-undangan. Hasil penelitian menunjukan bahwa Implementasi kebijakan energi baru dan energi terbarukan dalam rangka ketahanan energy nasional telah berjalan sebagaimana mestinya. Hal tersebut dapat dilihat dari dari peran pemerintah untuk mengadakan kebijakan (beleid) dan tindakan pengurusan (bestuursdaad), pengaturan (regelendaad), pengelolaan (beheersdaad) dan pengawasan (toezichthoudensdaad) untuk tujuan sebesar-besarnya kemakmuran rakyat.
\end{abstract}

Kata kunci: Kebijakan Energi, Energy Terbarukan, Ketahanan Energi Nasional 


\section{A. Pendahuluan}

Penggunaan energi di Indonesia masih di dominasi oleh penggunaan energi tak terbarukan yang berasal dari fosil, khususnya minyak bumi dan batu bara ${ }^{1}$, namun seiring berjalannya waktu, ketersediaan energi fosil semakin menipis dan untuk mengantisipasinya energi baru terbarukan (EBT) merupakan alternatif terbaik ${ }^{2}$. Penggunaan energi baru dan terbarukan harus menjadi perhatian utama pemerintah Indonesia tidak hanya sebagai upaya untuk mengurangi pemakaian energi fosil melainkan juga untuk mewujudkan energi bersih atau ramah lingkungan ${ }^{3}$.

Kekayaan sumber energi yang ada di Indonesia dikuasai oleh negara sebagaimana diatur dalam Konstitusi, yaitu pada pasal 33 ayat (3) Undang Undang Dasar 1945 yang berbunyi “ bumi dan air dan kekayaan alam yang terkandung di dalamnya dikuasai oleh negara dan dipergunakan untuk sebesar-besar kemakmuran rakyat “. Secara tegas Pasal 33 ayat (3) UUD NRI 1945 mengandung 3 (tiga) unsur penting, yaitu: ${ }^{4} 1$. Substansi (sumber daya alam); 2. Status (dikuasai oleh negara); 3. Tujuan (untuk sebesar-besarnya kemakmuran rakyat). Berdasarkan konstitusi, eksistensi penguasaan dan pengusahaan sumber daya alam yang fundamental bagi kehidupan berbangsa dan bernegara dilakukan oleh negara ${ }^{5}$.

Rakyat secara kolektif dikonstruksikan oleh UUD 1945 memberikan mandat kepada negara untuk mengadakan kebijakan (beleid) dan tindakan pengurusan (bestuursdaad), pengaturan (regelendaad), pengelolaan (beheersdaad) dan pengawasan (toezichthoudensdaad) untuk tujuan sebesar-besarnya kemakmuran rakyat ${ }^{6}$. Maka seluruh sumber energi harus dikuasai oleh negara dan wajib dipergunakan serta

\footnotetext{
${ }^{1}$ Muhammad Azhar, The New Renewable Energy Consumption Policy of Rare Earth Metals to Build Indonesia's National Energy Security, Conference Guidelines The $1^{\text {st }}$ Sriwijaya Internasional Conference on Environmental Issues, di Hotel Horison Ultima, Palembang, Indonesia, 26 - 27 September 2018, hlm. 86.

${ }^{2}$ Biro Komunikasi, Layanan Informasi Publik dan Kerja Sama Kementerian Energi dan Sumber Daya Mineral, Jurnal Energi : Program Strategis EBTKE dan Ketenagalistrikan, Edisi 02, 2016, hlm. 9.

${ }^{3}$ Aan Jaelani, Renewable Energy Policy in Indonesia: The Qur'anic Scientific Signals in Islamic Economics Perspective, International Journal of Energy Economics and Policy, Vol.7 No.4, 2017, hlm. 193.

4 Zen Umar Purba, Kepentingan Negara dalam Industri Perminyakan Indonesia, Hukum Internasional, Konstitusi dan Globalisasi, Jurnal Hukum Internasional Vol.4 No.2, Januari 2007, Lembaga Pengkajian Hukum Internasional, FH Universitas Indonesia, halaman 257-258.

${ }^{5}$ Ahmad Redi, Hukum Pertambangan Indonesia, Jakarta: Gramata Publishing, 2014, hlm. 3.

${ }^{6}$ Komisi Yudisial Republik Indonesia, Kompilasi Putusan Pengujian UU Oleh MK : Putusan Yang Dikabulkan Tahun 2003 - 2015, Jakarta: Biro Rekrutmen, Advokasi, dan Peningkatan Kapasitas Hakim, Komisi Yudisial Republik Indonesia, 2015, hlm. 1009.
} 
diusahakan secara optimal untuk sebesar-besar kemakmuran rakyat Indonesia, guna mewujudkan salah satu cita-cita bangsa Indonesia yaitu memajukan kesejahteraan umum.

Penggunaan energi meningkat pesat sejalan dengan pertumbuhan ekonomi dan pertambahan penduduk ${ }^{7}$. Perkembangan teknologi yang semakin pesat memicu peningkatan kebutuhan akan energi, dalam hal ini peningkatan akan kebutuhan tenaga listrik dalam kehidupan sehari-hari masyarakat semakin meningkat. Konsumsi tenaga listrik selama lima tahun (2012-2016) terakhir mengalami peningkatan rata-rata $6,7 \%$ pertahun $^{8}$.

Energi listrik, sebagai salah satu hasil pemanfaatan kekayaan alam dan teknologi mempunyai peranan penting bagi negara dalam mewujudkan pencapaian tujuan pembangunan nasional ${ }^{9}$. Energi listrik seakan menjadi kebutuhan primer masyarakat. Pergeseran kebutuhan energi ini dalam kebutuhan hidup masyarakat tampak nyata di masa depan dengan kemajuan teknologi, seperti mulai dikembangkannya kompor elektrik, alat transportasi eletrik, dan alat-alat pemenuh kebutuhan manusia lainnya yang berbahan dasar listrik sebagai penggeraknya.

Kebutuhan masyarakat akan energi listrik terus bertumbuh setiap tahunnya ${ }^{10}$. Dalam waktu yang akan datang kebutuhan listrik akan terus meningkat seiring dengan adanya peningkatan dan perkembangan baik dari jumlah penduduk, jumlah investasi, perkembangan teknologi termasuk didalamnya perkembangan dunia pendidikan untuk semua jenjang pendidikan ${ }^{11}$. Guna memenuhi pertumbuhan kebutuhan listrik yang semakin meningkat, pemerintah terus berupaya untuk mengembangkan teknologi dan membangun pembangkit-pembangkit tenaga listrik yang sesuai dengan asumsi pertumbuhan ekonomi dan proyeksi kebutuhan listrik.

\footnotetext{
${ }^{7}$ Syamsir Abduh, Pengelolaan Dana Ketahanan Energi, Mineral \& Energi, Vol.14 No.2, Juni 2016, Jakarta: Badan Penelitian dan Pengembangan Energi dan Sumber Daya Mineral, Kementerian Energi dan Sumber Daya Mineral, hlm. 4.

${ }^{8}$ Draft RUPTL PLN 2018-2027, hlm. IV-1.

${ }^{9}$ Komisi Yudisial Republik Indonesia, Op.cit, hlm. 1097.

${ }^{10}$ Muhamad Bobby Fadillah, Analisis Prakiraan Kebutuhan Energi Listrik Tahun 2015-2024 Wilayah PLN Kota Pekanbaru Dengan Metode Gabungan, Jurnal Online Mahasiswa Fakultas Teknik, Vol.2 No.2, 2015, hlm. 1.

${ }^{11}$ Ahmad Wahid, Analisis Kapasitas dan Kebutuhan Daya Listrik untuk Menghemat Penggunaan Energi Listrik di Fakultas Teknik Universitas Tanjungpura, Jurnal Teknik Elektro Universitas Tanjungpura, Vol.2 No.1, 2014, hlm. 2.
} 
Pada dasarnya program pengembangan pembangkit tenaga listrik merupakan proyek pembangunan ketenagalistrikan yang diharapkan dapat menerapkan secara maksimal Asas Manfaat dalam pembangunan ketenagalistrikan sesuai Undang-Undang Nomor 30 Tahun 2009 tentang Ketenagalistrikan. Yang dimaksud dengan "asas manfaat" adalah bahwa hasil pembangunan ketenagalistrikan harus dapat dimanfaatkan sebesar-besarnya bagi kesejahteraan dan kemakrnuran rakyat ${ }^{12}$.

Dalam usaha penyediaan tenaga listrik guna memenuhi peningkatan kebutuhan listrik masyarakat di seluruh wilayah Indonesia, Pemerintah dalam UU No.30 Tahun 2009 tentang Ketenagalistrikan telah menyatakan bahwa usaha penyediaan tenaga listrik untuk kepentingan umum dilaksanakan oleh badan usaha milik negara, badan usaha milik daerah, badan usaha swasta, koperasi dan swadaya masyarakat.

UU Ketenagalistrikan menyatakan bahwa badan usaha milik negara diberikan prioritas pertama dalam melakukan usaha penyediaan tenaga listrik untuk kepentingan umum. Badan usaha milik negara yang diberi prioritas pertama guna melakukan usaha penyediaan tenaga listrik adalah Perusahaan Listrik Negara (PLN). Penunjukan PLN sebagai badan usaha penyedia tenaga listrik telah sesuai dengan amanat konstitusi dalam pasal 33 ayat 2 UUD NRI 1945 yang mengatakan bahwa cabang-cabang produksi yang penting bagi negara dan yang menguasai hajat hidup orang banyak dikuasai oleh negara.

Pengusahaan dan penyediaan tenaga listrik adalah suatu cabang produksi yang penting bagi negara dan menguasai hajat hidup orang banyak, maka sudah tepat apabila PLN selaku badan usaha milik negara ditunjuk guna melakukan usaha penyediaan tenaga listrik. PLN adalah perusahaan yang diberi hak dan wewenang khusus serta tanggung-jawab pembangkitan, transmisi dan distribusi tenaga listrik yang berlaku di seluruh wilayah Indonesia sesuai dengan PP RI No.18 tahun $1972^{13}$. PLN berkewajiban menyediakan tenaga listrik dalam jumlah yang cukup kepada masyarakat di seluruh Indonesia secara terus menerus, baik dalam jangka pendek maupun jangka panjang.

\footnotetext{
${ }^{12}$ Penjelasan Pasal 2 ayat (1) huruf a UU No.30 Tahun 2009 tentang Ketenagalistrikan

${ }^{13}$ Pasal 7 Peraturan Pemerintah Nomor 18 Tahun 1972 Tentang Perusahaan Umum "Listrik Negara"
} 
Dalam melaksanakan peningkatan usaha penyediaan tenaga listrik. PLN berkewajiban menyusun sebuah dokumen tentang perencanaan sepuluh tahunan ke depan yang disebut Rencana Usaha Penyediaan Tenaga Listrik (RUPTL), hal ini sesuai dengan ketentuan Peraturan Pemerintah No.10 Tahun 1989 tentang Penyediaan dan Pemanfaatan Tenaga Listrik sebagaimana telah dua kali diubah dan perubaran yang terbaru yakni dengan

\section{B. Pembahasan}

\section{Kebijakan Pemerintah dalam Bentuk Peraturan Kebijakan menurut Hukum Administrasi}

Menurut Kamus Umum Belanda Indonesia, kata beleid' berarti kebijakan ${ }^{14}$. Dalam kepustakaan Belanda, ada berbagai istilah yang dipergunakan untuk menujuk eksistensi peraturan kebijakan, antara lain pseudowetgeving, spiegelrecht, dan beleidsregel $^{15}$. Dalam Kamus Besar Bahasa Indonesia memberikan pengertian kata "kebijakan" sebagai berikut ${ }^{16}$ :

Dalam perundang-undangan di Indonesia kata kebijakan disebut dalam Undangundang Nomor 25 Tahun 2004 tentang Sistem Perencanaan Pembangunan Nasional, tepatnya pada pasal 1 angka 15 yang berbunyi "Kebijakan adalah arah/tindakan yang diambil oleh Pemerintah Pusat/Daerah untuk mencapai tujuan.”

Menurut P.J.P Tak, seperti dikutip S.F Marbun pengertian peraturan kebijakan yakni ${ }^{17}$ :

"Beleidsregels zijn algemene regel die een bestuursinstantie stelt omtrent de uitoefening van ee bestuursbevoegheid jegens de burgers of een andere bestuursinstantie en voor welke regelstelling de grondwet nochde formele wet direct een uitdrukkelijke gronslag biedien Beleidsregels berusten dus niet op een bevoegdheid tot wetgeving en kunnen daarom ook geen algemeen verbindende voorschriften zijnmaar op een bestuursbevoedg heid van een bestuursorgaan en betreffen de uitoefening van die bevoegdheden.” (peraturan kebijaksanaan adalah peraturan umum yang

\footnotetext{
${ }^{14}$ Wojowasito, Kamus Umum Belanda Indonesia, Jakarta: Ichtiar Baru - Van Hoeve, 1995, hlm. 66.

${ }^{15}$ Hotma, P. Sibuea, Asas Negara Hukum, Peraturan Kebijakan \& Asas-asas Umum Pemerintahan yang Baik, Jakarta : Penerbit Erlangga, 2010, hlm.101

${ }^{16}$ Departemen Pendidikan Nasional, Kamus Besar Bahasa Indonesia Pusat Bahasa, Jakarta: Gramedia Pustaka Utama, 2008, hlm. 190.

${ }^{17}$ S.F Marbun, Op.cit, hlm. 174.
} 
dikeluarkan oleh instansti pemerintahan berkenaan dengan pelaksanaan wewenang pemerintah terhadap warga negara atau terhadap instansi pemerintahan lainnya dan pembuatan perundangan tersebut tidak memiliki dasar yang tegas dalam UUD dan undang-undang formal baik langsung maupun tidak langsung. Artinya peraturan kebijaksanaan tidak didasarkan pada kewenangan pembuatan undang-undang - dan oleh karena itu tidak termasuk peraturan perundang-undangan yang mengikat umum - tetapi diletakkan pada wewenang pemerintah suatu organ administrasi negara dan terksit dengan pelaksanan pemerintah.)

Pelaksanaan pemerintahan sehari-hari menunjukkan betapa badan atau pejabat tata usaha negara seringkali menempuh berbagai langkah kebijaksanaan tertentu, antara lain menciptakan apa yang kini sering dinamakan peraturan kebijaksanaan

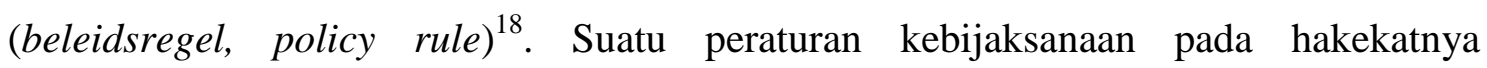
merupakan produk dari perbuatan tata usaha negara yang bertujuan "naar buiten gebracht schriftelijk beleid (menampakkan keluar suatu kebijakan tertulis)" namun tanpa disertai kewenangan pembuatan peraturan dari badan atau pejabat tata usaha negara yang menciptakan peraturan kebutuhan tersebut ${ }^{19}$. Peraturan kebijakan pada dasarnya diciptakan oleh pejabat administrasi negara untuk melaksanakan tugas-tugas pemerintah, yang merupakan konsekuensi atas negara hukum kesejahteraan yang membebankan tugas yang sangat luas kepada pemerintah untuk menyelenggarakan kesejahteraan rakyat (welfare state) ${ }^{20}$.

Peraturan kebijakan ini pada dasarnya memberikan peluang bagaimana suatu badan atau pejabat administrasi negara untuk menjalankan kewenangan pemerintahan (beschikking bevoegheid) dalam rangka penyelenggaraan tugas-tugas pemerintahan ${ }^{21}$. Dalam implementasinya peraturan kebijakan dapat diuji dengan melihat ciri-cirinya. Secara singkat, Van Kreveld mengemukakan bahwa peraturan kebijakan memiliki ciriciri sebagai berikut ${ }^{22}$ :

\footnotetext{
${ }^{18}$ Philipus M. Hadjon, Pengantar Hukum Admninistrasi Indonesia, Yogyakarta : Gadjah Mada University Press, 1999, hlm. 152.

${ }^{19}$ Philipus M. Hadjon, Loc.cit.

${ }^{20}$ Hotma, P. Sibuea, Loc.cit.

${ }^{21}$ Philipus M. Hadjon, Op.cit, hlm 153.

${ }^{22}$ Hotma, P. Sibuea, Op.cit, hlm. 104.
} 
1. Peraturan itu, langsung ataupun tidak langsung, tidak berdasar pada ketentuan formele wet maupun Grondwet yang memberikan kewenangan mengatur, dengan perkataan lain tidak mempunyai dasar hukum yang tegas dalam wet.

2. Peraturan itu dapat: a). Tidak tertulis, kemudian terhadi serangkaian keputusan instansi pemerintah yang berdiri sendiri dalm rangka menyelengarakan kewenangan pemerintah yang tidak terkait: b) ditetapkan dengan tegas secara tertulis oleh suatu instansi pemerintah.

3. Peraturan itu pada umumnya menunjukkan bagaimana suatu instansipemerintah akan bertindak, dalam menyelenggarakan kewenangan pemerintah yang tidak terikat, terhadap setiap orang dalam situasi sebagaimana dalam peraturan itu.

Seperti halnya Van Kreveld, Bagir Manan seperti dikutip oleh S.F. Marbun juga menyatakan beberapa ciri-ciri dari peraturan kebijakan sebagai berikut ${ }^{23}$ : a. Peraturan kebijaksanaan bukan merupakan peraturan perundang-undangan; b. Asas-asas pembatasan dan pengujian terhadap peraturan perundang-undangan tidak dapat diberlakukan pada peraturan kebijaksanaan; c. Peraturan kebijaksanaan tidak dapat diuji secara wetmatigheid, karena memang tidak ada dasar peraturan perundang-undangan untuk membuat peraturan kebijaksanaan tersebut; d. Peraturan kebijaksanaan dibuat berdasarkan Freies Ermessen dan ketiadaan wewenang administrasi bersangkutan membuat peraturan perundang-undangan; e. Pengujian terhadap peraturan kebijaksanan lebih diserahkan pada doelmatigheid sehingga batu ujinya adalah asas-asas umum pemerintahan yang baik; f. Dalam praktik diberi format dalam berbagai bentuk dan jenis aturan, yakni keputusan, instruksi, surat edaran, pengumuman, dan lain-lain, bahkan dapat pula dijumpai dalam bentuk peraturan.

Berkaitan dengan bentuknya Van Kreveld, menyatakan "peraturan kebijakan" dapat dituangkan dalam berbagai bentuk, seperti garis-garis kebijaksanaan (beleidslipijnen), kebijaksanaan (het beleid), peraturan (voorschriften), pedoman (rechtlijnen), petunjuk (regelingen), surat edaran (circularies), resolusi (resoluties), intruksi (aanschrijvingen), nota kebijaksanaan (beleids-nota's), peraturan menteri (reglemens ministriele), keputusan (beschikkingen), pengumuman (en

\footnotetext{
${ }^{23}$ S.F, Marbun, Op.cit., hlm. 175.
} 
bekendmakingen $)^{24}$. Selain itu menurut pendapat Phillip M. Hadjon, dalam praktik penyelenggaraan pemerintahan, ada peraturan kebijakan yang berbentuk pengumuman, pedoman, surat edaran, petunjuk teknis (juknis), petunjuk pelaksanaan (juklak), dan sebagainya ${ }^{25}$.

\section{Energi, Energi Baru dan Terbarukan Dalam Ketahanan Energi Nasional}

Istilah energi berasal dari bahasa Yunani, yaitu energia yang berarti ativitas (energos yang berarti aktif) ${ }^{26}$. Menurut Kamus Besar Bahasa Indonesia pengertian energi, yakni sebagai berikut ${ }^{27}$ : Ener.gi n Fis kemampuan untuk melakukan kerja (misalnya untuk energi listrik dan mekanika); daya (kekuatan) yang dapat digunakan untuk melakukan berbagai proses kegiatan, misalnya dapat merupakan bagian suatu bahan atau tidak terikat pada bahan (seperti sinar matahari); tenaga.

Energi adalah sumber daya yang dapat digunakan untuk melakukan berbagai proses kegiatan termasuk bahan bakar, listrik, energi mkanik dan panas ${ }^{28}$. Energi selalu berasal dari sumber energi, sumber energi adalah sesuatu yang dapat menghasilkan energi, baik secara langsung maupun melalui proses konversi atau transformasi ${ }^{29}$. Sumber energi merupakan sebagian dari sumber daya alam yang meliputi minyak dan gas bumi, batu bara, air, panas bumi, gambut, biomassa, dan sebagainya, baik secara langsung atau tidak langsung dapat dimanfaatkan sebagai energi ${ }^{30}$.

Pengertian energi terdapat pada Undang-undang Nomor 30 Tahun 2007 tentang Energi, yang tercantum pada bab I Ketentuan umum Pasal 1 angka (1) yakni Energi adalah kemampuan untuk melakukan kerja yang dapat berupa panas, cahaya, mekanika, kimia, dan elektromagnetika.

Sumber energi merupakan salah satu sumber daya alam ${ }^{31}$. Sebagai sumber daya alam, energi harus dimanfaatkan sebesar-besarnya bagi kemakmuran masyarakat dan

\footnotetext{
${ }^{24}$ S.F, Marbun, Op.cit, hlm. 176.

${ }^{25}$ Hotma, P. Sibuea, Op.cit, hlm. 107.

${ }^{26}$ Sutarno, Sumber Daya Energi, Yogyakarta : Graha Ilmu, 2013, hlm. 1.

${ }^{27}$ Departemen Pendidikan Nasional, Op.cit, hlm. 373

${ }^{28}$ Daryanto, Energi : Masalah dan Pemanfaatannya Bagi Kehidupan Manusia, Yogyakarta: Pustaka Widyatama, 2007, hlm. 9.

${ }^{29}$ Lihat Undang-Undang Nomor 30 Tahun 2007 tentang Energi pasal 1 ayat (2).

${ }^{30}$ Daryanto, Loc.cit.

${ }^{31}$ Daryanto, Op.Cit, hlm. 26
} 
pengelolaannya harus mengacu pada asas pembangunan berkelanjutan ${ }^{32}$. Jadi, sumber daya energi adalah sumber daya alam yang dapat diolah oleh manusia sehingga dapat digunakan bagi pemenuhan kebutuhan energi ${ }^{33}$. Sumber daya energi ini disebut sumber energi primer, yaitu sumber daya energi dalam bentuk apa adanya yang tersedia di alam $^{34}$.

Sumber daya energi merupakan kekayaan alam sebagaimana diamanatkan oleh segenap rakyat Indonesia melalui Pasal 33 Undang-Undang Dasar Negara Republik Indonesia Tahun 1945 negara memiliki kuasa terhadapnya dan wajib dipergunakan untuk sebesar-besarnya kemakmuran rakyat. Peranan energi sangat penting artinya bagi peningkatan kegiatan ekonomi dan ketahanan nasional, sehingga pengelolaan energi yang meliputi penyediaan, pemanfaatan, dan pengusahaannya harus dilaksanakan secara berkeadilan, berkelanjutan, optimal, dan terpadu ${ }^{35}$.

Alam telah menyediakan sumber energi secara gratis dan melimpah untuk dimanfaatkan oleh seluruh mahluk hidup. Namun untuk mendukung aktivitas hidup umat manusia di muka bumi, manusia juga perlu mengelola dan mengembangkan energi-energi yang sudah tersedia di alam, guna memenuhi kebutuhan hidupnya.

Dalam Pasal 2 Undang-Undang Nomor 30 Tahun 2007, diatur asas-asas dalam melakukan pengusahaan dan pengelolaan energi, yaitu : Asas Kemanfaatan; Asas Efisiensi Berkeadilan; Asas Peningkatan Nilai Tambah; Asas Keberlanjutan; Asas Kesejahteraan Masyarakat; Asas Pelestarian Fungsi Lingkungan; Asas Ketahanan Nasional; Asas Keterpaduan

Asas-asas dalam mengelola energi yang tercantum pada pasal 2 Undang-Undang Energi memiliki penjelasan masing-masing sebagai berikut ${ }^{36}$ : Asas kemanfaatan, maksud dari asas ini adalah dalam usaha pengelolaan energi harus memenuhi kebutuhan masyarakat; Asas efisiensi berkeadilan, maksud dari asas ini adalah dalam pengelolaan energi harus mencapai pemerataan akses terhadap energi dengan harga yang ekonomis dan terjangkau; Asas peningkatan nilai tambah, maksud dari asas ini adalah dalam pengelolaan energi harus mencapai nilai ekonomi yang optimal; Asas

\footnotetext{
${ }^{32}$ Elinur, Loc.cit.

${ }^{33}$ Sutarno, Op.cit, hlm. 3.

${ }^{34}$ Loc.cit.

${ }^{35}$ Lihat Undang-Undang Nomor 30 Tahun 2007 tentang Energi bagian Menimbang huruf b.

${ }^{36}$ Penjelasan pasal 2 Undang-undang Republik Indonesia Nomor 30 Tahun 2007.
} 
keberlanjutan, maksud dari asas ini adalah dalam pengelolaan energi harus menjamin penyediaan dan pemanfaatan energi untuk generasi sekarang dan yang akan datang; Asas kesejahteraan masyarakat, maksud dari asas ini adalah dalam pengelolaan energi harus mencapai kesejahteraan masyarakat yang sebesar-besarnya; Asas pelestarian fungsi lingkungan, maksud dari asas ini adalah dalam pengelolaan energi harus menjamin kualitas fungsi lingkungan yang lebih baik; Asas ketahanan nasional, maksud dari asas ini adalah dalam pengelolaan energi harus mencapai kemampuan nasional dalam pengelolaan energi; Asas keterpaduan, maksud dari asas ini adalah pengelolaan energi harus mencapai pengelolaan energi secara terpadu antar sektor.

Melalui asas-asas dalam melakukan pengusahaan dan pengelolaan energi yang diyatakan dalam Undang-Undang nomor 30 Tahun 2007 tentang Energi, diharapkan arah pengusahaan, pembangunan, dan pengelolaan energi nasional dapat mewujudkan pembangunan energi berkeadilan. Energi berkeadilan adalah memberikan akses energi secara merata kepada seluruh rakyat Indonesia melalui pembangunan infrastruktur sektor ESDM serta pengoptimalan potensi sumber energi setempat dengan harga terjangkau dan berkelanjutan, hal ini sesuai dengan amanat Undang-Undang Dasar 1945 Pasal 33, yakni energi harus digunakan sebesar-besarnya kemaslahatan rakyat, bangsa dan negara ${ }^{37}$.

Dalam pasal 33 Undang-Undang Dasar Negara Republik Indonesia Tahun 1945, negara diberikan mandat untuk menguasai seluruh sumber daya energi dengan tujuan agar dipergunakan secara bijak demi sebesra-besarnya kemakmuran seluruh rakyat Indonesia.

Energi baru adalah energi yang dikembangkan dari hasil ristek dan pengembangan teknologi yang tidak dapat dimasukkan dalam kelompok energi fosil atau energi terbarukan, contonya seperti energi nuklir, energi plasma (magneto hidro dinamika), atau energi cell bahan bakar (fuel cell) ${ }^{38}$. Energi baru merupakan jenis-jenis energi yang perkembangannya didorong oleh intervensi teknologi.

37 Kementerian Energi dan Sumber Daya Mineral, Lomba Foto Energi Berkeadilan, https://www.esdm.go.id/id/page/lomba-foto-energi-berkeadilan-2018 (diakses pada 04 November 2018, pukul 20.37)

${ }^{38}$ Ariono Abdulkadir, Seri Ketenagalistrikan Jilid 2: Energi Baru, Terbarukan dan Konservasi Energi, Bandung: ITB, 2011, hlm. 115. 
Menurut Undang-Undang Nomor 30 Tahun 2007 tentang Energi, pengertian Energi Baru terdapat pada pasal 1 ayat (5) yakni energi yang berasal dari sumber energi baru. Sedangkan, Sumber energi baru adalah sumber energi yang dapat dihasilkan oleh teknologi baru baik yang berasal dari sumber energi terbarukan maupun sumber energi tak terbarukan, antara lain nuklir, hidrogen, gas metana batu bara (coal bed methane), batu bara tercairkan (liquified coal), dan batu bara tergaskan (gasified coal) ${ }^{39}$.

Pada pengertian sumber energi baru dalam Undang-Undang Nomor 30 Tahun 2007 tentang Energi telah diklasifikasikan macam-macam jenis energi baru, yakni nuklir, hidrogen, gas metana batu bara (coal bed methane), batu bara tercairkan (liquified coal), dan batu bara tergaskan (gasified coal). Dalam hal penguasaan dan pengaturannya, sumber energi baru diserahkan oleh rakyat kepada negara dan dimanfaatkan sebesar-besanya untuk sebesar-besar kemakmuran rakyat.

Pengertian energi terbarukan adalah energi yang berasal dari sumber energi terbarukan $^{40}$. Sumber energi terbarukan adalah sumber energi yang dapat digunakan tanpa batas waktu dan tidak akan pernah habis karena dapat dipulihkan dalam waktu relatif singkat ${ }^{41}$. Menurut Undang-undang Nomor 30 Tahun tentang Energi, pengertian energi terbarukan tercantum pada pasal 1 ayat (6), yakni " sumber energi yang dihasilkan dari sumber daya energi yang berkelanjutan jika dikelola dengan baik, antara lain panas bumi, angin, bioenergi, sinar matahari, aliran dan terjunan air, serta gerakan dan perbedaan suhu lapisan laut.”

Sumber energi terbarukan adalah sumber energi yang sangat ramah lingkungan, karena tidak menghasilkan pencemaran lingkungan dan tidak termasuk salah satu penyebab dari perubahan iklim dan pemanasan global, karena energi yang dihasilkan berasal dari proses alam yang berkelanjutan seperti angin, air, sinar matahari, panas bumi, dan biofuel ${ }^{42}$. Negara Indonesia adalah negara yang memiliki potensi sumber energi terbarukan dalam jumlah yang sangat besar karena pengaruh astronomis dan geografis negara Indonesia. Potensi sumber energi terbarukan yang terkandung di Indonesia seperti energi panas bumi, surya, air, laut/samudra, bioenergi.

\footnotetext{
${ }^{39}$ Undang-Undang Nomor 30 Tahun 2007 tentang Energi pasal 1 ayat (4).

${ }^{40}$ Lihat Undang-undang Nomor 30 Tahun 2007 tentang Energi Pasal 1 ayat (7)

${ }^{41}$ Daryanto, Op.Cit, hlm. 26.

${ }^{42}$ Kementerian Sumber Daya Energi dan Mineral, Loc.cit
} 
Indonesia terletak di garis khatulistiwa yang menyebabkan Indonesia beriklim tropis, mayoritas daerah-daerah di Indonesia senantiasa di sinari terik matahari. Berdasarkan data penyinaran matahari yang dihimpun dari 18 lokasi di Indonesia menunjukan bahwa radiasi surya di Indonesia dapat diklasifikasikan berturut turut sebagai berikut : untuk kawasan barat dan timur Indonesia dengan distribusi penyinaran di Kawasan Barat Indonesia sekitar $4.5 \mathrm{kWh} / \mathrm{m} 2$.hari dengan variasi bulanan sekitar $10 \%$ dan Kawasan Timur Indonesia sekitar $5.1 \mathrm{kWh} / \mathrm{m} 2$.hari dengan variasi bulanan sekitar 9\%, dengan demikian potensi penyinaran matahari di Indonesia rata-rata sekitar $4.8 \mathrm{kWh} / \mathrm{m} 2$.hari dengan variasi bulanan sekitar $9 \%{ }^{43}$.

Indonesia adalah negara yang juga kaya akan potensi panas bumi, karena termasuk dari daerah vulkanik. Hal ini disebabkan karena kondisi geografis Indonesia yang dilewati oleh jalur Cincin Api yakni jalur gunung berapi membentang di Indonesia dari ujung Pulau Sumatera sepanjang Pulau Jawa, Bali, NTT, NTB menuju Kepulauan Banda, Halmahera, dan Pulau Sulawesi. Berdasarkan survei menunjukkan bahwa terdapat 70 lokasi panas bumi bertemperatur tinggi dengan kapasitas total mencapai 19.658 MW. Sebagian besar dari lokasi tersebut belum dilakukan eksploitasi secara intensif ${ }^{44}$.

Selanjutnya Indonesia memiliki potensi besar untuk pengembangan pembangkit listrik tenaga air, karena terdapat sumber energi tenaga air yang melimpah di Indonesia. Potensi ini disebabkan kondisi topografi Indonesia bergunung dan berbukit serta dialiri oleh banyak sungai dan daerah daerah tertentu mempunyai danau/waduk yang cukup potensial sebagai sumber energi air ${ }^{45}$.

Indonesia sebagai negara agraris mempunyai potensi biomassa yang relatif besar yang berasal dari limbah pertanian, perkebunan, kehutanan, limbah ternak dan limbah kota (sampah) ${ }^{46}$.

Secara umum Indonesia masuk kategori negara tanpa angin, mengingat bahwa kecepatan angin minimum rata-rata yang secara ekonomis dapat dikembangkan sebagai

\footnotetext{
${ }^{43}$ Abubakar Lubis, "Energi Terbarukan dalam Pembangunan Berkelanjutan", Jurnal Teknik Lingkungan, Vol.8 No.2, Mei 2007, hlm. 161.

${ }^{44}$ Loc.cit.

${ }^{45}$ Ibid, hlm. 157.

${ }^{46}$ Daryanto, Op.Cit, hlm. 111.
} 
penyedia jasa energi adalah $4 \mathrm{~m} / \mathrm{dt}^{47}$. Namun di beberapa wilayah Indonesia memiliki potensi akan sumber energi angin. Wilayah tersebut antara lain Nusa Tenggara Timur (NTT), Nusa Tenggara Barat (NTB), Sulawesi Selatan dan Tenggara, Pantai Utara dan Selatan Jawa dan Karimun Jawa.

Indonesia adalah negara yang kaya akan potensi energi laut/samudra, karena Indonesia adalah negara kepulauan yang memiliki lebih banyak perairan daripada daratan. Luas wilayah laut Indonesia adalah $65 \%$ dari total seluruh wilayah Indonesia yakni 3.544.743,9 km², dengan garis pantai yang membentang sepanjang $81.000 \mathrm{~km}$, yang terdiri dari laut dalam dan laut dangkal. Dengan melihat luas wilayah laut dan samudra negara Indonesia, dapat diperkirakan bahwa Indonesia memiliki sumber energi laut/samudra berupa energi panas laut, energi pasang surut, energi gelombang, energi arus laut yang dapat menghasilkan energi listrik.

\section{Simpulan}

Implementasi kebijakan energi baru dan energi terbarukan dalam rangka ketahanan energy nasional telah berjalan sebagaimana mestinya. Hal tersebut dapat dilihat dari dari peran pemerintah untuk mengadakan kebijakan (beleid) dan tindakan pengurusan (bestuursdaad), pengaturan (regelendaad), pengelolaan (beheersdaad) dan pengawasan (toezichthoudensdaad) untuk tujuan sebesar-besarnya kemakmuran rakyat. Pengelolaan kebijakan energi baru dan energi terbarukan tertuang dalam Undang-Undang Nomor 30 Tahun 2007. Pengelolaan energi baru dan energi terbarukan harus senan tiasa berdasarkan pada asas-asas dalam melakukan pengusahaan dan pengelolaan energi, yaitu : Asas Kemanfaatan; Asas Efisiensi Berkeadilan; Asas Peningkatan Nilai Tambah; Asas Keberlanjutan; Asas Kesejahteraan Masyarakat; Asas Pelestarian Fungsi Lingkungan; Asas Ketahanan Nasional; Asas Keterpaduan.

\section{Daftar Pustaka}

Aan Jaelani, Renewable Energy Policy in Indonesia: The Qur'anic Scientific Signals in Islamic Economics Perspective, International Journal of Energy Economics and Policy, Vol.7 No.4, 2017

Abubakar Lubis, "Energi Terbarukan dalam Pembangunan Berkelanjutan", Jurnal Teknik Lingkungan, Vol.8 No.2, Mei 2007

\footnotetext{
${ }^{47}$ Abubakar Lubis, Op.cit, hlm 160.
} 
Ahmad Redi, Hukum Pertambangan Indonesia, Jakarta: Gramata Publishing, 2014.

Ahmad Wahid, Analisis Kapasitas dan Kebutuhan Daya Listrik untuk Menghemat Penggunaan Energi Listrik di Fakultas Teknik Universitas Tanjungpura, Jurnal Teknik Elektro Universitas Tanjungpura, Vol.2 No.1, 2014.

Ariono Abdulkadir, Seri Ketenagalistrikan Jilid 2: Energi Baru, Terbarukan dan Konservasi Energi, Bandung: ITB, 2011.

Biro Komunikasi, Layanan Informasi Publik dan Kerja Sama Kementerian Energi dan Sumber Daya Mineral, Jurnal Energi : Program Strategis EBTKE dan Ketenagalistrikan, Edisi 02, 2016.

Daryanto, Energi : Masalah dan Pemanfaatannya Bagi Kehidupan Manusia, Yogyakarta: Pustaka Widyatama, 2007.

Departemen Pendidikan Nasional, Kamus Besar Bahasa Indonesia Pusat Bahasa, Jakarta: Gramedia Pustaka Utama, 2008.

Diktum kedua Keputusan Menteri Energi dan Sumber Daya Mineral Republik Indonesia Nomor 1567 K/21/MEM/2018 Tentang Pengesahan Rencana Usaha Penyediaan Tenaga Listrik PT Perusahaan Listrik Negara Persero Tahun 2018 s.d 2027.

Hotma, P. Sibuea, Asas Negara Hukum, Peraturan Kebijakan \& Asas-asas Umum Pemerintahan yang Baik, Jakarta : Penerbit Erlangga, 2010,

IPP (Independent Power Producer) adalah perusahaan produsen listrik swasta yang dibentuk oleh konsosium untuk melakukan perjanjian PPA dengan PLN.

Kementerian Energi dan Sumber Daya Mineral, Executive Summary RUPTL PT PLN (PERSERO) 2018-2027, dalam acara Diseminasi RUPTL 2018-2027, Jakarta, 22 Maret 2018,

Kementerian Energi dan Sumber Daya Mineral, Lomba Foto Energi Berkeadilan, https://www.esdm.go.id/id/page/lomba-foto-energi-berkeadilan-2018 (diakses pada 04 November 2018, pukul 20.37)

Komisi Yudisial Republik Indonesia, Kompilasi Putusan Pengujian UU Oleh MK : Putusan Yang Dikabulkan Tahun 2003 - 2015, Jakarta: Biro Rekrutmen, Advokasi, dan Peningkatan Kapasitas Hakim, Komisi Yudisial Republik Indonesia, 2015, hlm. 1009.

Muhamad Bobby Fadillah, Analisis Prakiraan Kebutuhan Energi Listrik Tahun 20152024 Wilayah PLN Kota Pekanbaru Dengan Metode Gabungan, Jurnal Online Mahasiswa Fakultas Teknik, Vol.2 No.2, 2015

Muhammad Azhar, The New Renewable Energy Consumption Policy of Rare Earth Metals to Build Indonesia's National Energy Security, Conference Guidelines

The 1st Sriwijaya Internasional Conference on Environmental Issues, di Hotel Horison Ultima, Palembang, Indonesia, 26 - 27 September 2018

Philipus M. Hadjon, Pengantar Hukum Admninistrasi Indonesia, Yogyakarta : Gadjah Mada University Press, 1999,

Sutarno, Sumber Daya Energi, Yogyakarta : Graha Ilmu, 2013

Syamsir Abduh, Pengelolaan Dana Ketahanan Energi, Mineral \& Energi, Vol.14 No.2, Juni 2016, Jakarta: Badan Penelitian dan Pengembangan Energi dan Sumber Daya Mineral, Kementerian Energi dan Sumber Daya Mineral,

Undang-Undang Nomor 30 Tahun 2007 tentang Energi

Wojowasito, Kamus Umum Belanda Indonesia, Jakarta: Ichtiar Baru - Van Hoeve, 1995 , 
Zen Umar Purba, Kepentingan Negara dalam Industri Perminyakan Indonesia, Hukum Internasional, Konstitusi dan Globalisasi, Jurnal Hukum Internasional Vol.4 No.2, Januari 2007, Lembaga Pengkajian Hukum Internasional, FH Universitas Indonesia, 